\title{
Significance of monazite EPMA ages from the Quamby Conglomerate, Queensland
}

\author{
P. M. EVINS ${ }^{1 *}$, A. R. WILDE ${ }^{2 \dagger}$, D. R. W. FOSTER ${ }^{1}$, S. W. MCKNIGHT ${ }^{3}$ AND \\ T. G. BLENKINSOP'
}

'School of Earth Sciences, James Cook University, Q/d 4811, Australia.

${ }^{2}$ pmd*CRC, Monash University, Vic. 3800, Australia.

${ }^{3}$ School of Science \& Engineering, University of Ballarat, PO Box 663, Ballarat, Vic. 3353, Australia.

\begin{abstract}
Th $U \mathrm{~Pb}$ electron microprobe (EPMA) dating of mainly detrital monazite from the Quamby Conglomerate in the Eastern Succession of the $\mathrm{Mt}$ Isa inlier reveals three distinct monazite growth/ recrystallisation events at around 1640, 1580 and 1490 Ma. These ages are particularly significant with respect to the timing of deposition, iron and gold mineralisation, and deformation in the Mt Isa inlier. The oldest age probably represents provenance from igneous rocks. In the sample, the majority of monazite growth occurred at $1580 \mathrm{Ma}$, coeval with peak metamorphism in the Eastern Succession. The low metamorphic grade of the conglomerate and wide compositional range of monazite bearing this age indicates that the monazite grew elsewhere and was later deposited in the conglomerate. Purple bands in the rock are composed mainly of coarse specular hematite with recrystallised margins that contribute to high (up to 20\%) $\mathrm{Fe}_{2} \mathrm{O}_{3}$ contents in the conglomerate. Gold is also present in some of the samples. Some of the monazite grains contain small, younger (ca $1490 \mathrm{Ma}$ ) domains that may have grown/recrystallised in situ during a lower grade syn or post diagenetic metamorphic/hydrothermal event that may have been related to hematite (re)crystallisation. Together, these ages bracket deposition of the Quamby Conglomerate to between ca 1580 and $1490 \mathrm{Ma}$, the latter age most likely representing diagenesis. This depositional age also represents a maximum age for north south striking, upright folds of the Quamby Conglomerate and implies that significant ductile deformation has affected parts of the Mt Isa inlier after $1580 \mathrm{Ma}$ and probably after $1490 \mathrm{Ma}$.
\end{abstract}

KEY WORDS: electron microprobe microanalysis, geochronology, gold, monazite, Mt Isa, Quamby Conglomerate.

\section{INTRODUCTION}

The Quamby Conglomerate outcrops in fault-bounded blocks $10 \mathrm{~km}$ west and southwest of Quamby in the eastern succession of the Mt Isa Proterozoic terrane (Figure 1). In the Quamby fault zone, the conglomerate abuts subunits of the Corella Formation (as mapped) that have recently given a depositional age of $1650 \pm 3 \mathrm{Ma}$ (Page \& Sun 1998). The conglomerate is unlikely to belong to units deposited prior to this as it underwent only low-grade metamorphism (probably sub-greenschist) and abuts an andalusite schist (Foster \& Rubenach 2006) near the southernmost extent of outcrop $30 \mathrm{~km}$ south of the Quamby mine (Figure 1). The large difference in metamorphic grade implies that the Quamby Conglomerate was juxtaposed with the adjacent schist after the peak of metamorphism. Idnurm and Wyborn (1998) suggested that the conglomerate was deposited at $c a 1500 \mathrm{Ma}$ based on palaeomagnetic data and therefore that the conglomerate represents a rare vestige of post-metamorphic Proterozoic sedimentary rock in the Mt Isa region. The possibility also exists that this unit was a reservoir or repository for oxidised brine involved in the formation of iron oxide copper gold deposits of the region, such as the nearby Ernest Henry $\mathrm{Cu} \mathrm{Au}$ deposit.

The conglomerate was mined for gold during the nineteenth century and more recently during the 1990s. Production was minor, and the most recent operation reported mining by opencut and heap leach of reserves of $122000 \mathrm{t}$ at $3.7 \mathrm{~g} / \mathrm{t} \mathrm{Au}$, for production of $123.9 \mathrm{~kg}$ of gold bullion (Denaro et al. 2004). There has been little published work on the Quamby Conglomerate apart from that of Idnurm and Wyborn (1998). The objective of this contribution is to present $\mathrm{Th} \mathrm{U} \mathrm{Pb}$ electron microprobe ages of monazite as well as whole-rock 
X-ray diffraction and bulk chemical data from the Quamby Conglomerate.

\section{QUAMBY CONGLOMERATE IN OUTCROP}

The Quamby Conglomerate crops out well, and particularly good exposures are afforded by the abandoned Quamby gold mine. At map scale, the conglomerate occurs as three thin, fault-bounded blocks of uncertain thickness (Figure 1). In the block north of the mine, bedding defines a shallow basin (dips $<30^{\circ}$ ) while in

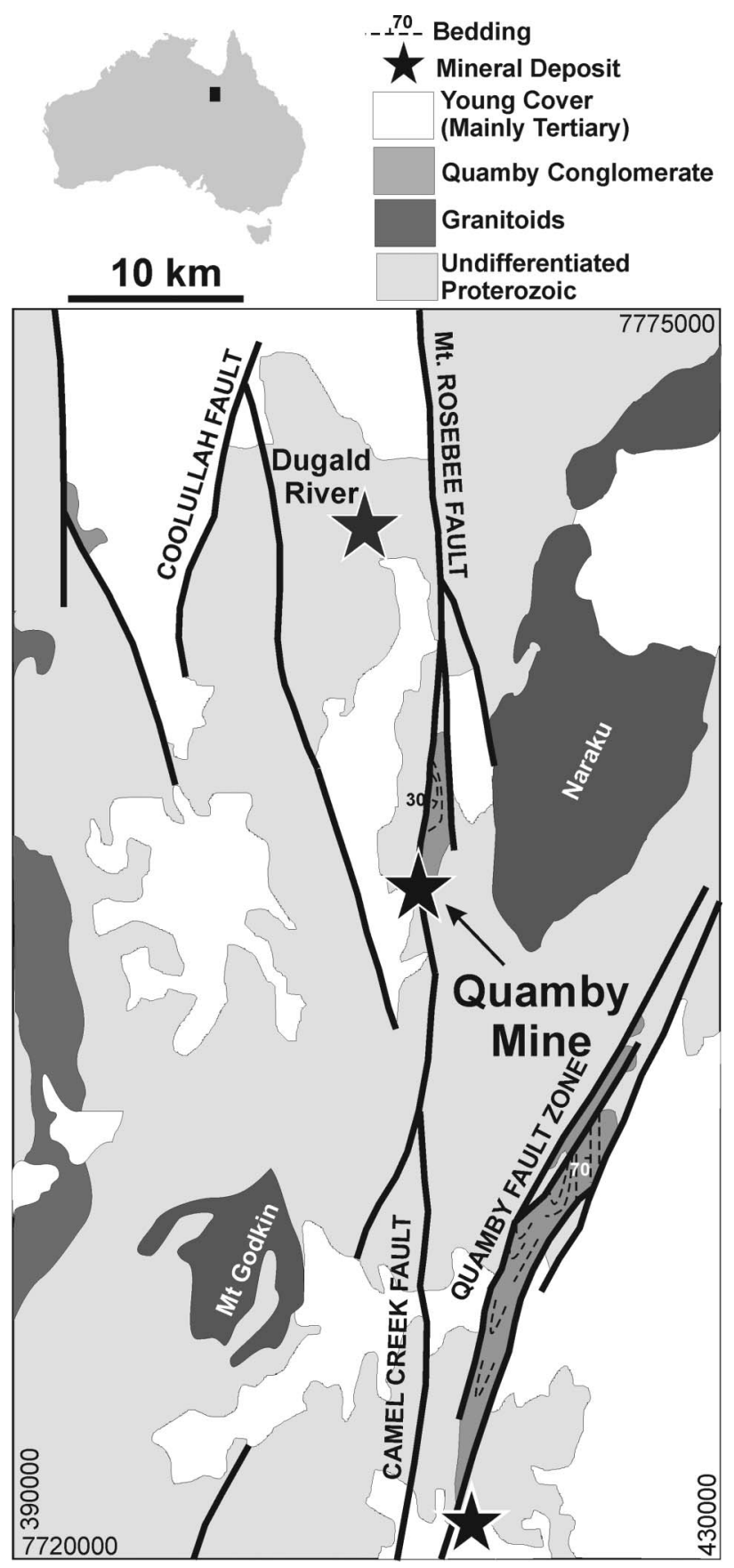

Figure 1 Geological setting of the Quamby Conglomerate. the block south and southeast of the mine, bedding is tightly folded about north south-trending axes with steeply dipping axial planes. These folds are cut by the bounding faults (Derrick 1980; Wilson et al. 1980).

As noted by Idnurm and Wyborn (1998), the conglomerate is polymict, containing a variety of subrounded clasts that include slate, schist and quartzite. At the Quamby gold mine, the pebbles are typically several centimetres in maximum dimension and make up between 5 and $70 \%$ by volume of the rock. Conglomerate forms a distinct layer in the mine which overlies a sanddominated unit containing a much smaller proportion of pebbles. A defining feature of the conglomerate is ubiquitous specular hematite concentrated in thin sedimentary layers (Figure 2a). There is no evidence of a post-diagenetic hydrothermal origin for these hematitic layers, such as fracture control or association with quartz veins, and they appear to be laterally very continuous.

The Quamby gold mine is one of few, if not the only, fresh exposures of the Quamby Conglomerate. Here, dips are shallow, and there is no evidence of folding or cleavage development. A north south-trending fault, paralleling the major Mt Rosebee and Camel Creek Faults (Figure 1) offsets bedding in the walls of the small openpit by a few metres of normal displacement. The disposition of the workings with respect to this fault suggests that the gold was concentrated along it. There is a conspicuous dearth of quartz veins along this structure, although veins appear to have been prospected adjacent to the main mine workings. Cataclasite is developed to a distance of $1 \mathrm{~m}$ each side of the fault, and consists of conglomerate and sandstone fragments in a purplish matrix of friable clay, clastic quartz, and iron. Samples were taken to best characterise the conglomerate in the vicinity of the $\mathrm{Au}$ deposit and potentially date as many geological events that have affected the conglomerate. From a number of thin-sections, only one contained monazite.

\section{MINERALOGY AND BULK CHEMICAL COMPOSITION}

The total iron concentration of the samples (from powdered matrix plus pebbles) can be estimated from the data in Table 1 to be up to $20 \% \mathrm{Fe}_{2} \mathrm{O}_{3}$, making these rocks extremely iron rich. None of the other analysed elements (Table 1) have particularly anomalous concentrations except gold in samples AW04-001 and AW04-002 (19 ppm and $0.7 \mathrm{ppm}$, respectively). Modal mineralogy of four samples was quantified using X-ray diffraction (XRD: University of Ballarat) and SiroQuant ${ }^{\mathrm{TM}}$ ver2.5 software (Table 1). The analysis suggests that the rocks consist mainly of only four minerals: quartz, hematite, 2M muscovite and kaolinite. Minor albite was detected in AW04-003, but the $0.9 \%$ volume is close to the detection limit for this technique.

The hematite layers are dominantly composed of $400 \mu \mathrm{m}$ plates of euhedral to subhedral, coarse, specular hematite (Figure 2b). Semi-quantitative energydispersive X-ray (EDX) analyses of the hematite reveal detectable Ti and rarely $\mathrm{V}$. No evidence of zoning was found. It is unlikely that this coarse hematite was 


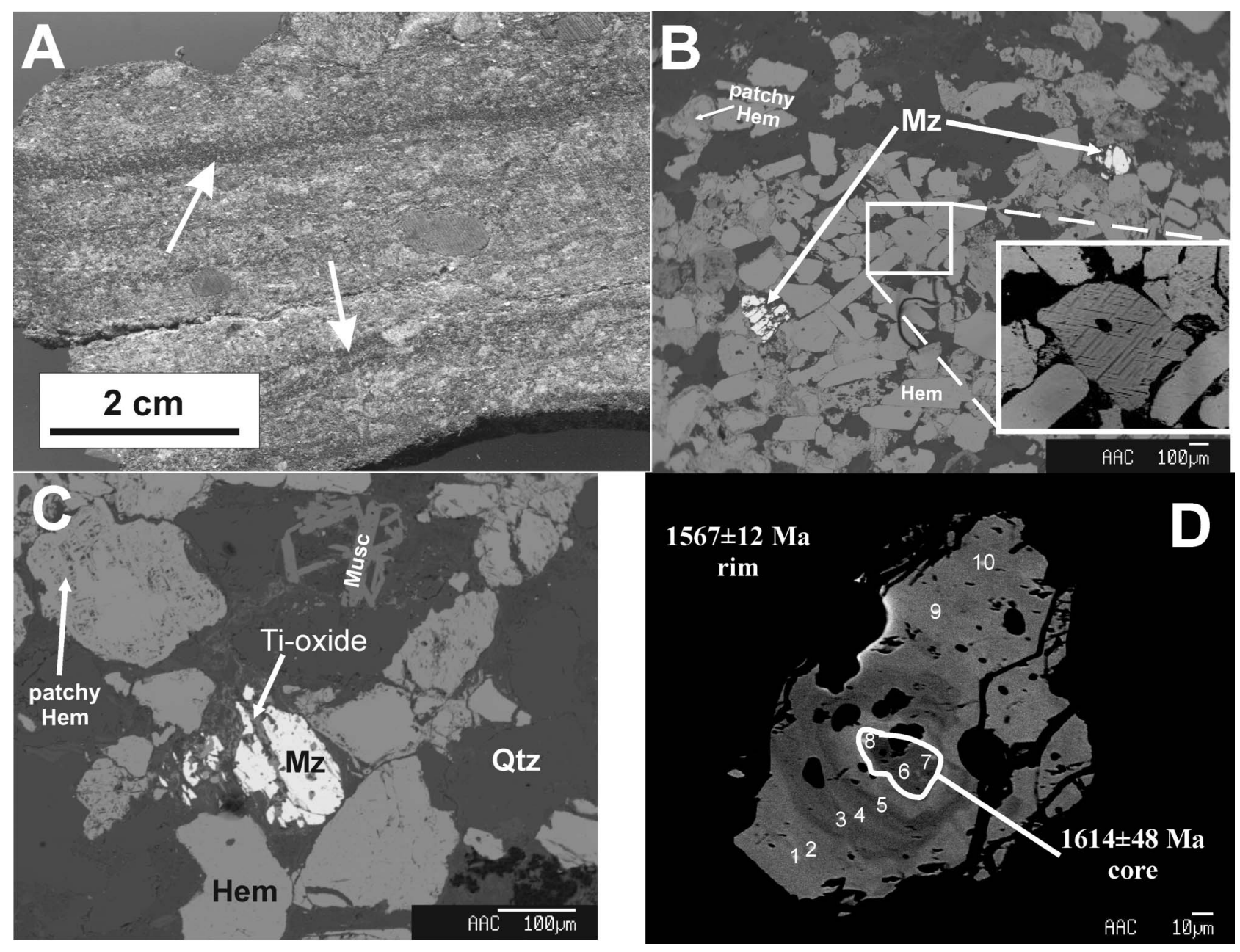

Figure 2 Images of the Quamby Conglomerate (sample AW04 004). (a) Hand specimen showing layers enriched in purple hematite and ilmenite (arrowed). The remaining portion of the rock contains an earthy red oxide. (b) Hematite rich band with backscatter electron (BSE) bright monazite. Many of the hematite grains show evidence of marginal recrystallisation. Note the detrital ilmenite grain with Ti rich lamellae illustrated in the inset. (c) Close up of rounded monazite grain 5 showing Ti oxide filled fractures. (d) BSE image of monazite grain 3 with older, dark core surrounded by younger concentrically zoned monazite. Numbers correspond to analytical points in Table 3.

Table I Pebble composition, modal mineralogy (XRD) and trace element (ppm) chemical compositions of Quamby Conglomerate samples.

\begin{tabular}{lcccc}
\hline & AW04 001 & AW04 002 & AW04 003 & AW04 004 \\
\hline Pebbles (quartz) & $70 \%$ & $60 \%$ & $30 \%$ & $20 \%$ \\
Quartz & $76.70 \%$ & $67.60 \%$ & $62.80 \%$ & $35.10 \%$ \\
Muscovite & $15.10 \%$ & $16.30 \%$ & $18.10 \%$ & $33.60 \%$ \\
Hematite & $8.20 \%$ & $16.10 \%$ & $16.30 \%$ & $19.90 \%$ \\
Kaolinite & $0.00 \%$ & $0.00 \%$ & $2.00 \%$ & $11.50 \%$ \\
Albite (low) & $0.00 \%$ & $0.00 \%$ & $0.90 \%$ & $0.00 \%$ \\
ppm & & & & \\
Au & 18.71 & 0.78 & 0.08 & 0.08 \\
As & 2 & 4 & 3 & 7 \\
$\mathrm{Ba}$ & 104 & 206 & 117 & 134 \\
$\mathrm{Bi}$ & 0.1 & 0.07 & 0.14 & 0.06 \\
$\mathrm{Co}$ & 13 & 10 & 15 & 12 \\
$\mathrm{Cu}$ & 25 & 18 & 18 & 51 \\
$\mathrm{~Pb}$ & 2 & 4 & 6 & 4 \\
$\mathrm{U}$ & 8.4 & 8.9 & 10.1 & 7.8 \\
$\mathrm{Zn}$ & 14 & 12 & 20 & 11 \\
$\mathrm{Zr}$ & 95 & 105 & 211 & 141 \\
\hline
\end{tabular}

detrital because it is too angular and abundant in the rock. Instead, the coarse hematite is interpreted as a diagenetic alteration of detrital $\mathrm{Fe}$ oxide and ilmenite grains. Locally, fairly equant, $\sim 200 \mu \mathrm{m}$, subangular ilmenite grains show exsolution lamellae of $\mathrm{Ti}$ oxide under backscattered electron images (Figure $2 \mathrm{~b}$ ) indicating that they were originally igneous grains that now reside as detrital grains. Both types of coarse oxide grains are surrounded by masses of fine-grained platy hematite and locally a discrete Ti oxide. These platy hematite grains show random orientation (Figure 2b) and are interpreted to be the product of recrystallisation of the coarser grains. No systematic variation in $\mathrm{Ti} / \mathrm{Fe}$ between coarse and fine hematite has thus far been detected.

Relatively coarse bent and fractured muscovite is another detrital phase. However, most muscovite occurs as a very fine-grained filling of pore space between detrital quartz and hematite. Traces of pore-filling chlorite have also been noted, but chlorite is not sufficiently abundant to register on bulk XRD traces. 
Monazite is present in one of the samples and is usually associated with hematite, suggesting that the $\mathrm{Fe}$ oxide/monazite concentrations represent depositional heavy-mineral bands. Monazite grains are large (up to $200 \mu \mathrm{m}$ ), rounded to subangular, and usually equant with aspect ratios $<2$. They are invariably fractured with a $\mathrm{Ti}$ oxide or $\mathrm{Fe}$ hydroxide phase filling the fractures (Figure 2c).

\section{MONAZITE AGES}

\section{Analytical technique}

The sample thin-section was polished with $1 \mu \mathrm{m}$ diamond paste and carbon-coated before analysis with a 1 $5 \mu \mathrm{m}$ diameter beam at $15 \mathrm{keV}$ and $200 \mathrm{nA}$. The analytical setup for the JEOL JXA-8200 Superprobe at James Cook University is shown in Table 2. Background positions were chosen based on clean areas (no interfering peaks) from wavelength scans of eight standard monazites representing a variety of compositions up to $10 \mathrm{wt} \% \quad \mathrm{ThO}_{2}$ and $2 \mathrm{wt} \%$ S. Two-point linear backgrounds were used, as no curvature or abnormality above baseline was detected in the area between chosen background points. Collimators were opened to maximum $(3 \mathrm{~mm})$, pulse height analysis settings were optimised, calibrations were performed on the standards (Table 2), and $\mathrm{Th}, \mathrm{U}, \mathrm{Pb}$ and $\mathrm{Y}$ standards were analysed as samples for error propagation before unknown analyses. In addition, monazite from the Iveland pegmatites, Norway, was used as an internal standard yielding a weighted average age within error of its reported age of $1043 \pm 20 \mathrm{Ma}$ (M. Jercinovic pers.

Table 2 Analytical setup for EPMA monazite dating on the JEOL JXA 8200 Superprobe at James Cook University.

\begin{tabular}{|c|c|c|c|c|}
\hline $\begin{array}{l}\text { Element } \\
\text { peak }\end{array}$ & Standard & $\begin{array}{c}\text { Crystal } \\
\text { spectrometer }\end{array}$ & $\begin{array}{l}\text { Background } \\
\pm(\mathrm{mm})\end{array}$ & $\begin{array}{c}\text { Count } \\
\text { time (s) } \\
\text { peak/ } \\
\text { background }\end{array}$ \\
\hline $\mathrm{PK}^{\mathrm{a}}$ & $\mathrm{CePO}_{4}{ }^{\mathrm{c}}$ & TAP 1 & $3 / 4$ & $20 / 10$ \\
\hline $\mathrm{PbM}^{\mathrm{a}}$ & $\mathrm{PbSiO}_{3}{ }^{\mathrm{a}}$ & PETJ $2^{\mathrm{d}}$ & $4 / 6$ & $180 / 90$ \\
\hline $\mathrm{DyL}^{\mathrm{b}}$ & $\mathrm{DyPO}_{4}{ }^{\mathrm{c}}$ & LIFH $3^{\mathrm{d}}$ & $1 / 4$ & $40 / 20$ \\
\hline $\mathrm{UM}^{\mathrm{b}}$ & $\mathrm{U}^{\mathrm{a}}$ & PETJ 4 & $3.5 / 2.5$ & $180 / 90$ \\
\hline $\mathrm{ThM}^{\mathrm{a}}$ & $\mathrm{ThO}_{2}{ }^{\mathrm{b}}$ & PETJ 5 & $2.5 / 3$ & $90 / 45$ \\
\hline $\mathrm{YL}^{\mathrm{a}}$ & $\mathrm{YPO}_{4}{ }^{\mathrm{c}}$ & TAP 1 & $1.25 / 2$ & $90 / 45$ \\
\hline $\mathrm{GdL}^{\mathrm{b}}$ & $\mathrm{GdPO}_{4}{ }^{\mathrm{c}}$ & LIFH $3^{\mathrm{d}}$ & $1 / 1$ & $40 / 20$ \\
\hline $\mathrm{CaK}^{\mathrm{a}}$ & $\mathrm{CaSiO}_{3}{ }^{\mathrm{a}}$ & PETJ 5 & $1.6 / 1.6$ & $20 / 10$ \\
\hline $\mathrm{SiK}^{\mathrm{a}}$ & $\mathrm{PbSiO}_{3}{ }^{\mathrm{a}}$ & TAP 1 & $5 / 3$ & $20 / 10$ \\
\hline $\mathrm{SmL}^{\mathrm{b}}$ & $\mathrm{SmPO}_{4}{ }^{\mathrm{c}}$ & LIFH $3^{d}$ & $1 / 1$ & $40 / 20$ \\
\hline $\mathrm{SK}^{\mathrm{a}}$ & $\mathrm{BaSO}_{4}{ }^{\mathrm{a}}$ & PETJ $3^{\mathrm{d}}$ & $6 / 4$ & $30 / 15$ \\
\hline $\mathrm{NdL}^{\mathrm{b}}$ & $\mathrm{NdPO}_{4}{ }^{\mathrm{c}}$ & LIFH $3^{d}$ & $1 / 1$ & $10 / 5$ \\
\hline $\operatorname{PrL}^{b}$ & $\mathrm{PrPO}_{4}{ }^{\mathrm{c}}$ & LIFH $3^{d}$ & $1 / 1$ & $20 / 10$ \\
\hline $\mathrm{CeL}^{\mathrm{a}}$ & $\mathrm{CePO}_{4}{ }^{\mathrm{c}}$ & LIFH $3^{d}$ & $3.2 / 3.2$ & $10 / 5$ \\
\hline $\mathrm{LaL}^{\mathrm{a}}$ & $\mathrm{LaPO}_{4}{ }^{\mathrm{c}}$ & LIFH $3^{\mathrm{d}}$ & $1.6 / 1.6$ & $10 / 5$ \\
\hline
\end{tabular}

${ }^{\text {a Astimex }}$

braylor.

${ }^{\mathrm{c}} \mathrm{Pb}$ free synthetic from Pyle (Rennselaer Polytechnic Institute, USA).

d Sealed Xe detectors. comm. 2002). Each $\sim 7 \mathrm{~min}$ analysis allowed measurement of $\mathrm{U}, \mathrm{Th}$ and $\mathrm{Pb}$ concentrations to a suitable accuracy for age determinations as well as Y, Ca, Si, S, $\mathrm{La}, \mathrm{Ce}, \mathrm{Pr}, \mathrm{Nd}, \mathrm{Sm}, \mathrm{Gd}$ and Dy for accurate overlap (ThM $\zeta$ and $\mathrm{YL} \gamma$ on $\mathrm{Pb}$ and $\mathrm{ThM} \gamma$ over $\mathrm{UM} \beta$ ) and matrix (PAP) corrections. Errors for individual analyses (Table 3) were calculated by the Monte Carlo method of Lisowiec (2006). All ages in the text are weighted averages of several individual analyses with errors quoted at the $95 \%$ confidence level unless otherwise indicated. Age data from each monazite grain were treated individually. Discordant data from $\mathrm{Th} / \mathrm{Pb} \mathrm{U} / \mathrm{Pb}$ isochrons (Cocherie \& Albarede 2001) and $\mathrm{Th} * \mathrm{~Pb}$ isochrons (Suzuki \& Adachi 1991) were removed before age calculations. Data were grouped separately by backscatter electron (BSE) intensity, intragrain location (core, rim, etc.) and chemistry. Weighted average ages of each group were calculated, and any groups yielding disparate ages within $95 \%$ confidence errors were highlighted as possible geological events. Model ages were also calculated from an agedistribution histogram (Sambridge \& Compston 1994) to confirm these geological events among the monazite age populations.

\section{Results}

Forty-one EPMA (electron microprobe) analyses from five monazite grains in a single thin-section were used to determine the $\mathrm{Th} \mathrm{U} \mathrm{Pb}$ ages discussed below (Table 3). Grains 2, 4 and 5 are found in hematite bands, while grains 1 and 3 reside in the conglomerate matrix. Grains in the hematite bands generally exhibit similar age distributions to those outside of the bands, except for grain 5. All analyses plot along a single $\mathrm{U} / \mathrm{Pb} \mathrm{Th} / \mathrm{Pb}$ isochron (Cocherie \& Albarede 2001) to provide a tightly constrained age of $1580 \pm 16 \mathrm{Ma}$ (Figure 3a) similar to the weighted average of all ages at $1585 \pm 14 \mathrm{Ma}$. Although the weighted average ages of each of the grains are within error of this age, some contain distinctly older and younger components (Table 3). Grains 3 and 5 show core/rim relationships reflected by older ages in BSE dark cores and younger ages in BSE light rims. Grain 3 contains a small, chemically homogeneous, core aged $1614 \pm 48 \mathrm{Ma}$ surrounded by younger, $1567 \pm 12 \mathrm{Ma}$, concentrically zoned monazite (Figure $2 d)$. Ages from the Dy-, Y- and Si-rich core of grain 5 $(1586 \pm 23 \mathrm{Ma})$ are significantly older than those from its La- and P-enriched rim (1466 $\pm 68 \mathrm{Ma})$.

Mixture modelling (Sambridge \& Compston 1994) from a probability density histogram of the entire population of 41 analyses confirms the three age populations suggested by core/rim age relationships in grains 3 and 5 , and places tighter constraints on the age populations at $1486 \pm 19,1581 \pm 5$ and $1638 \pm 9 \mathrm{Ma}$ (Table 4; Figure 4a). Errors on these age populations should be treated liberally as they are generated from a small population. Individual analyses responsible for the older and younger outliers are not confined to single grains but are present in grains from both matrix and hematite bands (Figure 4a). The majority of analyses $(62 \%)$ from all of the grains define the $c a 1580 \mathrm{Ma}$ age, which is interpreted to represent peak metamorphism 


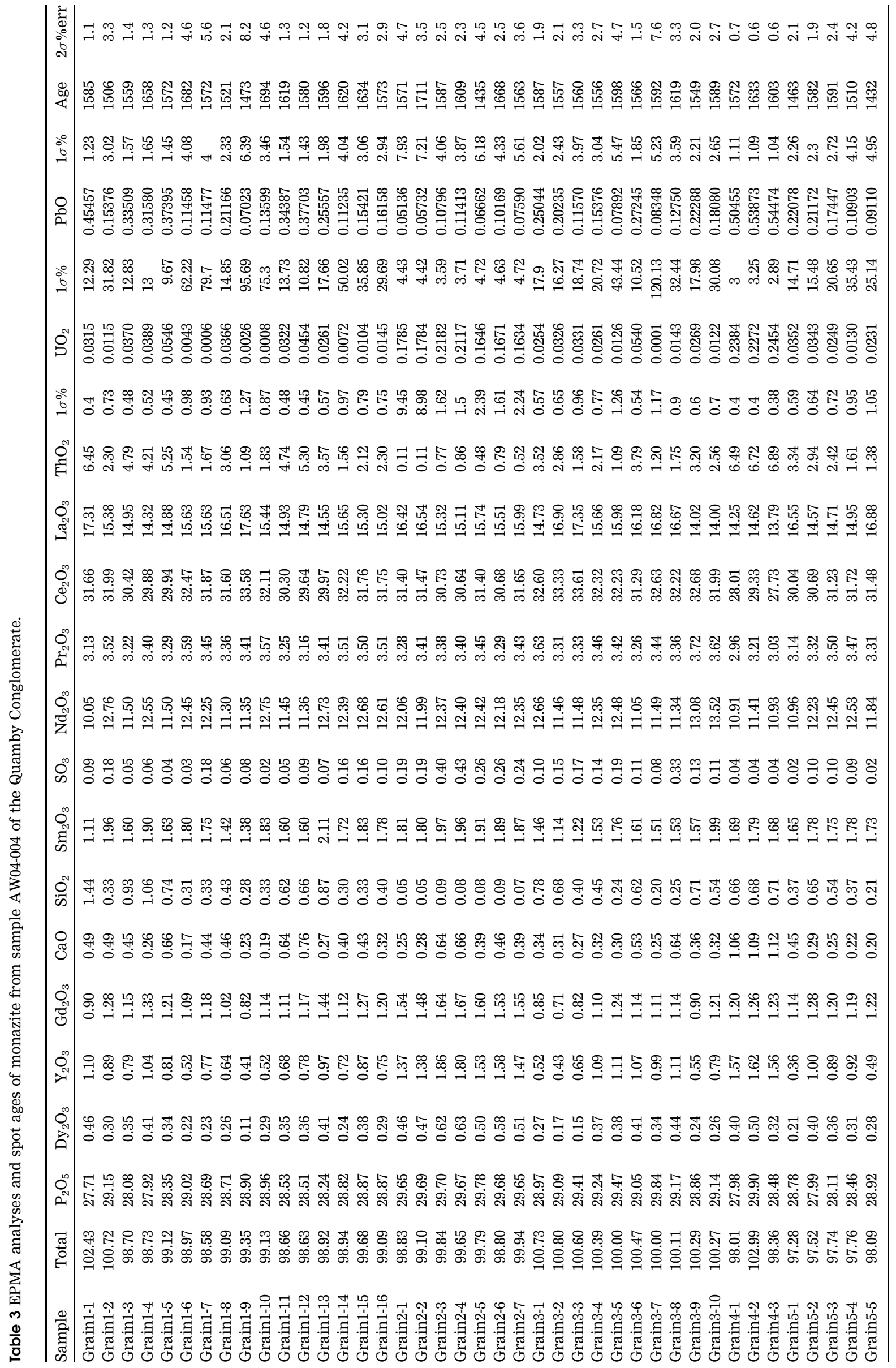


(a)

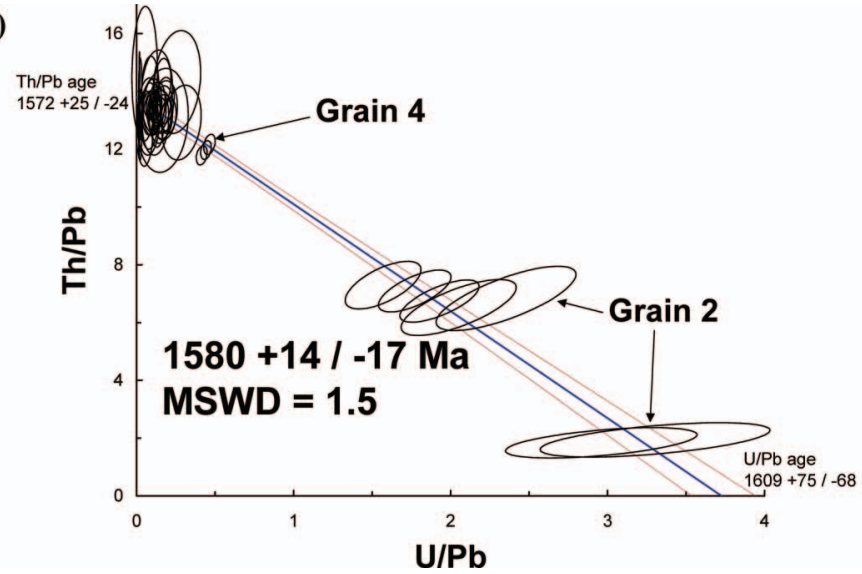

(b)

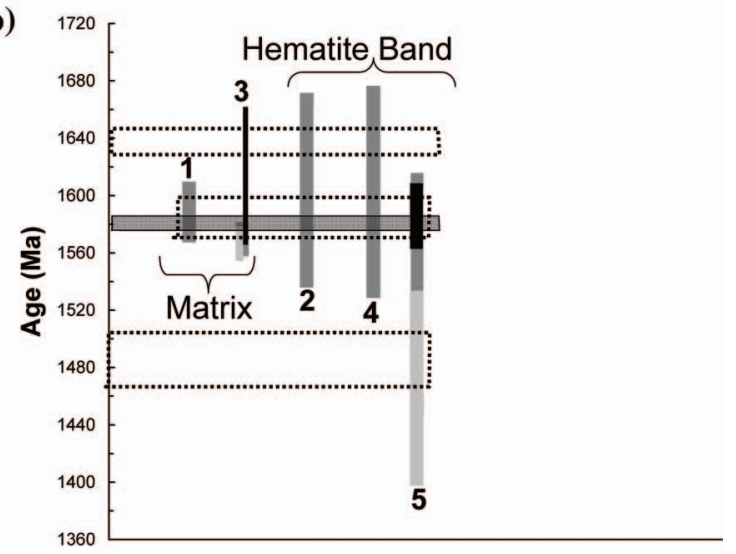

Figure 3 (a) Isochron plot of all monazite analyses from sample AW04 004 following the method of Cocherie and Albarede (2001). Both $\mathrm{Th} / \mathrm{Pb}$ and $\mathrm{U} / \mathrm{Pb}$ ages are within error of each other, indicating that the isochron age is valid. Error ellipses are $2 \sigma$. (b) Weighted average ages of individual grains (numbered gray bars) and cores (black) and rims (light gray) from grains 3 and 5. Weighted average of entire sample stretches across in transparent grey. Dotted boxes stretched across represent the three model ages derived from unmixing the entire set of ages in Isoplot. Bar heights represent $95 \%$ confidence limits.

Table 4 Weighted average ages for single monazite grains, intragrain domains and all spot analyses, as well as the isochron age and model ages from all analyses.

\begin{tabular}{lccc}
\hline Grain & Age & MSWD & No. of spots \\
\hline 1 entire grain & $1589 \pm 21$ & 7.5 & 16 \\
2 entire grain & $1604 \pm 68$ & 9 & 7 \\
3 entire grain & $1570 \pm 12$ & 1.03 & 10 \\
3 outer zones & $1567 \pm 12$ & 0.82 & 8 \\
3 core & $1614 \pm 48$ & 1.6 & 2 \\
4 entire grain & $1603 \pm 74$ & 31 & 3 \\
5 entire grain & $1531 \pm 85$ & 12 & 5 \\
5 core & $1586 \pm 23$ & 0.14 & 2 \\
5 rim & $1466 \pm 68$ & 1.5 & 3 \\
All grains & $1585 \pm 14$ & 1.6 & \\
Isochron age & $1580 \pm 16$ & 1.5 & \\
Model ages & $1486 \pm 19$ & & $15 \%$ \\
& $1581 \pm 5$ & & $62 \%$ \\
\hline
\end{tabular}

Percentages of model ages represent proportion of analyses represented by the corresponding age.

in the Eastern Succession (Page \& Sun 1998; Hand \& Rubatto 2002). Grains 2 and 4 from the same hematite band were entirely formed from this event, yet their chemistry is distinctly different (Figure 4c). This suggests that they are metamorphic monazite that grew in different hosts before they were deposited together in the Quamby Conglomerate. The older ca $1640 \mathrm{Ma}$ age in some of the grains is interpreted as an inherited component, possibly derived from $c a 1630 \mathrm{Ma}$ igneous rocks in the nearby Tommy Creek block. This old component is characterised by a restricted range in Sm content (Figure $4 \mathrm{~b}$ ). The youngest monazite domains are characterised by a generally lower huttonite $\left(\mathrm{ThSiO}_{4}\right)$ and brabantite $\left(\mathrm{CaTh}\left(\mathrm{PO}_{4}\right)_{2}\right)$ component (Figure 4b) with low Th levels typical of hydrothermal monazite (Tallarico \& McNaughton 2004).

\section{DEPOSITIONAL AGE AND IMPLICATIONS}

Three distinct ages, ca 1640, 1580 and $1490 \mathrm{Ma}$, are recorded by domains in monazite from the Quamby Conglomerate. These alone are insufficient to determine the depositional age of the Quamby Conglomerate. The ca 1640 monazite domains are interpreted here as inherited components of probable igneous origin. The ca 1580 Ma grouping exhibits the widest range in traceelement chemistry (Figure $4 \mathrm{~b}, \mathrm{c}$ ) and is likely to be of metamorphic origin. Two plausible depositional scenarios (Figure 5) emerge dependent upon whether the $c a$ $1580 \mathrm{Ma}$ monazite age reflects either (i) inherited (detrital) monazite grains of regional metamorphic affinity or (ii) peak metamorphic monazite growth in situ in the Quamby Conglomerate. The first scenario is most plausible for the following reasons: (i) the Quamby Conglomerate has not witnessed any highgrade metamorphism (no greenschist facies or highergrade metamorphic minerals were found in the matrix) of the type usually attributed to major monazite growth and effectively rules out in situ monazite growth in the conglomerate during a major metamorphic event; (ii) the monazite grains are concentrated in depositional bands (Figure $2 \mathrm{~b}$ ) and are of detrital appearance, i.e. large, highly fractured, and partially rounded (Figure 2c); and (iii) the individual monazite grains in the hematite bands are chemically distinct from one another suggesting they grew in different hosts (Figure $4 \mathrm{~b}$ ).

The minor ca $1490 \mathrm{Ma}$ age component of some monazites correlates with the $c a 1500 \mathrm{Ma}$ magnetic overprint event found in the Quamby Conglomerate by Idnurm and Wyborn (1998) and is coeval with ca $1500 \mathrm{Ma}$ plutons of the nearby Naraku Granite (which crops out $3 \mathrm{~km}$ away). Interpretation of this age as an inherited component cannot be excluded but is unlikely, given the low Th content typical of hydrothermal monazite (Tallarico \& McNaughton 2004) and common occurrence as rims. This late monazite component probably grew either during diagenesis and coarse hematite 

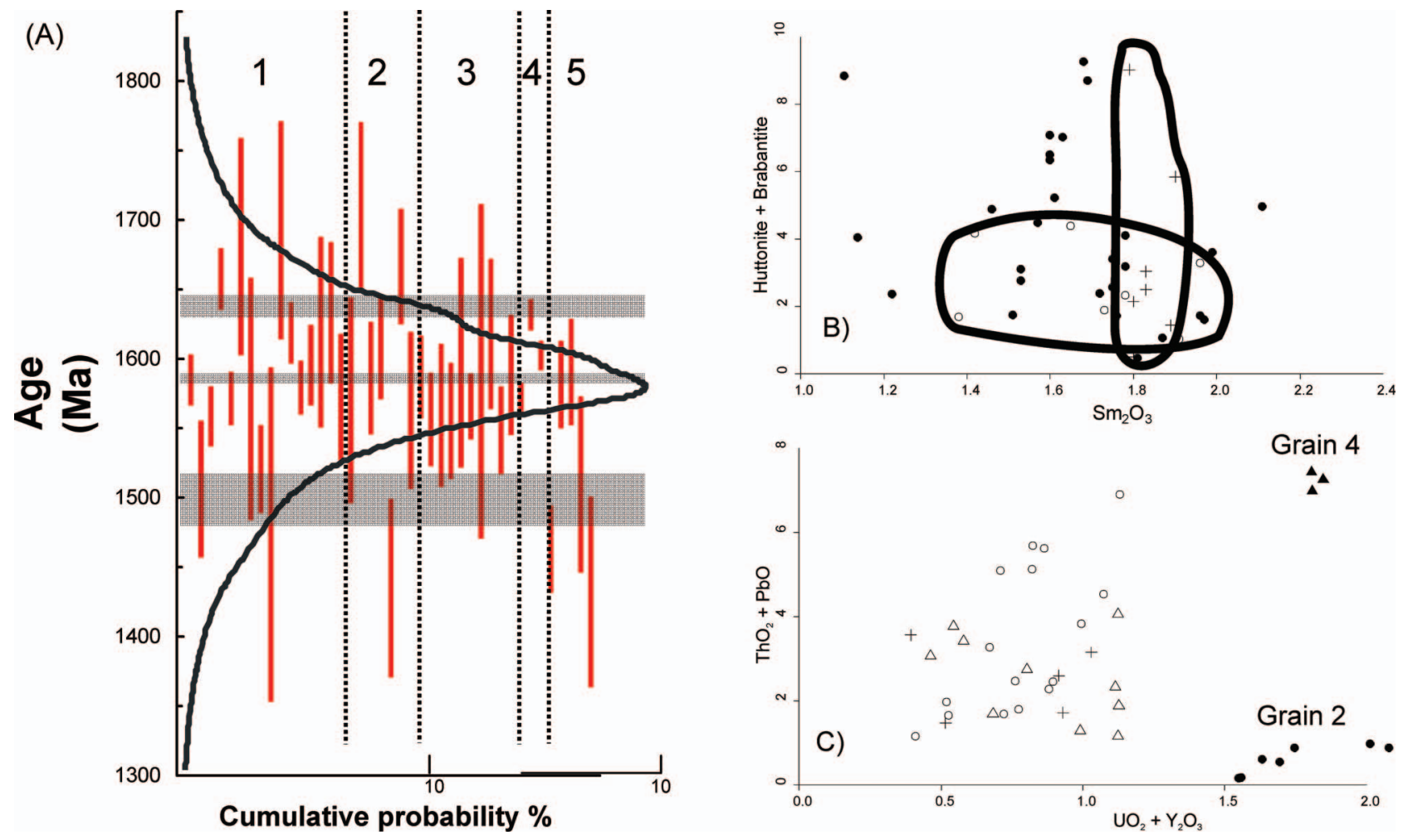

Figure 4 (a) Ages from all analyses in the order presented in Table 3. Grains labelled and subdivided by dotted lines. The probability density curve shows a main peak at $c a 1580 \mathrm{Ma}$ and a minor peak at ca $1640 \mathrm{Ma}$. Light grey bars represent model ages derived from unmixing the entire set of ages in Isoplot. Bar heights represent 95\% confidence limits. (b) Chemical distinctions of the youngest ca $1490 \mathrm{Ma}$ (empty circles), middle ca $1580 \mathrm{Ma}$ (dots) and oldest ca $1640 \mathrm{Ma}$ (crosses) age groupings. Note the restricted range of Sm content in the oldest age group and huttonite + brabantite component in the youngest group. (c) Variation in Y, Pb and actinides between grains 1 (empty circle), 2 (filled circle), 3 (empty triangle), 4 (filled triangle) and 5 (crosses). Note that although grains 2 and 4 are the same age, one contains higher Th and $\mathrm{Pb}$ concentrations than the other. This suggests they may be from different sources. Grains 2 and 4 are also distinctly richer in $\mathrm{U}$ and $\mathrm{Y}$ than the others.

\begin{tabular}{|c|c|c|c|}
\hline 1640 & $\mathbf{1 5 8 0}$ & $\mathbf{1 4 9 0}$ & $<\mathbf{1 4 9 0}$ \\
\hline $\begin{array}{c}\text { inherited igneous component } \\
\text { in detrital monazite cores }\end{array}$ & $\begin{array}{c}\text { detrital metamorphic monazite as } \\
\text { rims and entire grains }\end{array}$ & $\bullet$ limited hydrothermal monazite & $\bullet$ patchy hematite / oxy-chlorite \\
\hline $\begin{array}{c}\text { monazite cores represent } \\
\text { entire detrital component }\end{array}$ & $\begin{array}{c}\text { in situ metamorphic / } \\
\text { hydrothermal monazite }\end{array}$ & $\bullet$ limited hydrothermal monazite & \\
\hline
\end{tabular}

Figure 5 Two most plausible scenarios for the evolution of the Quamby Conglomerate based on direct age constraints from monazite and indirect age constraints from Idnurm and Wyborn (1998) (i.e. consistent palaeomagnetic poles from the coarse hematite indicate it is not detrital and crystallised before north south folding). Depositional age ranges are highlighted in grey.

crystallisation or during a later hydrothermal event responsible for thin veinlets of oxy-chlorite and finergrained hematite that overprint the coarse hematite and infill fractures in monazite. The time difference between coarse and patchy hematite may be very short if the growth of both hematite generations was due to continued diagenesis.

The age of coarse hematite growth is important when considering the palaeomagnetic data of Idnurm and Wyborn (1998). Consistent palaeomagnetic pole orientations measured from coarse hematite in multiple samples of the Quamby Conglomerate indicate that it grew in situ and before folding (Idnurm \& Wyborn 1998). The orientations of the palaeomagnetic poles place the Quamby Conglomerate at either a ca 1500 Ma position or ca 1100 Ma position along the northeast Australia polar wander path. Along with the monazite constraints on depositional age, this demonstrates that tight north south folding, which is indistinguishable from the style of ca $15951580 \mathrm{Ma} \mathrm{D}_{2}$ folding or $\mathrm{D}_{3}$ folding in the Mt Isa block, occurred post-1580 Ma, probably even post$1490 \mathrm{Ma}$, and possibly even younger than $1100 \mathrm{Ma}$. 
However, post-1100 Ma deformation in the Mt Isa block is unlikely, considering the undeformed state of the 1100 Ma Lakeview Dolerite (Page 1983). Regardless of whether folding of the Quamby Conglomerate was after 1580 or $1490 \mathrm{Ma}$, the ages of all north-south folding events in the Mt Isa block should be re-evaluated. In conclusion, total $\mathrm{Th}-\mathrm{U}-\mathrm{Pb}$ monazite ages indicate that the Quamby Conglomerate was most probably deposited between $\mathrm{ca} 1580$ and $1490 \mathrm{Ma}$ and underwent diagenesis at $c a 1490 \mathrm{Ma}$.

\section{ACKNOWLEDGEMENTS}

Thorough and thoughtful reviews by L. Hutton and G. M. Derrick helped improve the clarity of this contribution. The authors acknowledge the funding of the $p m d^{*} \mathrm{CRC}$ and of Xstrata Copper which helped make this study possible.

\section{REFERENCES}

Cocherie A. \& Albarede F. 2001. An improved U-Th-Pb age calculation for electron microprobe dating of monazite. Geochimica et Cosmochimica Acta 65, 4509-4522.

Denaro T. J., Culpeper L. G., Burrows P. E. \& Morwood D. A. 2004. Mines, mineralisation and mineral exploration in the Cloncurry 1:250 000 sheet area, north-west Queensland. Queensland Geological Record 2004/1.

DERRICK G. M. 1980. Marraba, Queensland 1:100000 Geological Map. Bureau of Mineral Resources, Canberra.
FOSTER D. R. W. \& RUBENACH M. J. 2006. Isograd pattern and regional low-pressure, high-temperature metamorphism of pelitic, mafic and calc-silicate rocks along an east-west section through the Mt Isa Inlier. Australian Journal of Earth Sciences 53, 167-186.

HAND M. \& RUBATTO D. 2002. The scale of the thermal problem in the Mt Isa Inlier. Geological Society of Australia Abstracts 67, 173.

IDNURM M. \& WYBORN L. 1998. A Mesoproterozoic palaeomagnetic age for the gold-bearing Quamby Conglomerate, Queensland. AGSO Research Newsletter 28, 6-7.

LISOWIEC N. 2006. Precision estimation in electron microprobe monazite dating: repeated measurements versus statistical (Poisson) based calculations. Chemical Geology 234, 223-235.

PAGE R. W. 1983. Chronology of magmatism, skarn formation and uranium mineralization, Mary Kathleen, Queensland, Australia. Economic Geology 78, 838-853.

PAGE R. W. \& SUN S-S. 1998. Aspects of geochronology and crustal evolution in the Eastern Fold Belt, Mt Isa Inlier. Australian Journal of Earth Sciences 45, 343-361.

SAMBRIDGE M. S. \& COMPSTON W. 1994. Mixture modeling of multicomponent data sets with application to ion-probe zircon ages. Earth and Planetary Science Letters 128, 373-390.

SUZUKI K. \& ADACHI M. 1991. Precambrian provenance and Silurian metamorphism of the Tsbonosawa paragneiss in the South Kitakami terrane, northeast Japan, as revealed by the chemical $\mathrm{Th}-\mathrm{U}$-total $\mathrm{Pb}$ isochron ages of monazite, zircon, and xenotime. Geochemical Journal 25, 357-376.

TAllarico F. H. B. \& MCNAughton N. J. 2004. Geological and SHRIMP II U-Pb constraints on the age and origin of the Breves $\mathrm{Cu}-\mathrm{Au}-(\mathrm{W}-\mathrm{Bi}-\mathrm{Sn})$ deposit, Carajas, Brazil. Mineralium Deposita 39, 68-86.

WiLson I. H., LitTLE M. R. \& RoberTson A. 1980. Quamby, Queensland 1:100000 Geological Map. Bureau of Mineral Resources, Canberra. 